\title{
Dialog Antar Umat Beragama Sebagai Piranti Menumbuhkan Sikap Toleransi
}

\author{
Imas Setiyawan \\ STAI Taruna Surabaya \\ setiyawanimas@gmail.com \\ Elfada Adella Hidayat \\ UIN Sunan Ampel Surabaya \\ fadaadella@gmail.com
}

\begin{abstract}
Inter-religious harmony has until now become a goal in the life of every human being. Where each individual or group continues to maintain an attitude of tolerance to always live peacefully in a country that has diverse ethnic groups, customs, culture and religion. Given that tolerance must be possessed by every human being on this earth. What about mutual respect, respecting the trust of others, and not forcing the truth to those who already have their own truth. Like religious tolerance, every human being must respect the worship procedure for other religions, teachings that they believe in in his religion and do not see one's religious background if he wants to help him. Dialogue, is one way for tolerance to be maintained in interfaith relations. With the dialogue between religious people, whether individuals or religious groups, it will be easier to express their thoughts without fear of arousing words of attacking one another. In every religion, such as Islam, Christianity, Buddhism, Hinduism, and Confucianism, views on tolerance and dialogue between religious groups are different. Although, it has the same meaning. Namely, both of them aim to continue to maintain the harmony of life between religious people. In this article, we will discuss interfaith dialogue, tolerance and dialogue in the perspective of religions. Also how can dialogue be a moral to foster an attitude of enthusiasm among religious people.
\end{abstract}

Keywords: Dialogue, Tolerance, Religions

\section{Pendahuluan}

Ketika kita memiliki keinginan untuk menciptakan kehidupan antar umat beragama yang damai. Masing-masing dari kita harus sama-sama saling menghormati keragaman yang ada. Mengingat masih ada keadaan di mana perilaku dalam kehidupan sosial sering dibalut dengan perasaan benci, curiga antar sesama, juga beberapa pesan-pesan damai dalam agama yang harusnya disampaikan dan dilakukan malah di simpan sendiri, sebagai penanda kebenaran hanya dimiliki oleh agamanya sendiri. Padahal, agama tidak selalu tentang dimensi batin. Dalam artian, agama tidak hanya seseorang itu berhubungan dengan Tuhan. Karena ada yang namanya dimensi lahir, di mana terwujud dari simbol-simbol atau perkumpulan sebuah jamaah. Maka dari itu ketika agama masuk dalam ranah sosial, tidak sebagai makhluk individu, melainkan jadi makhluk sosial. Di mana baik antara individu satu ke individu lainnya atau ke suatu kelompok tertentu pasti bertemu.

Melihat hal semacam itu, agama seharusnya bisa menjadi sebuah jawaban juga pengikat keutuhan antar seluruh umat manusia dalam meredam konflik-konflik yang biasa terjadi antar umat beragama. Ajaran dalam agama, tentang etika, akhlak, perilaku yang sopan, harus mulai biasa dilakukan oleh seluruh pemeluk agama. Mulai dari saling bertegur sapa, saling membantu, agar masing-masing dapat mengalahkan egonya dalam hal identitas 
keagamaan. Karena jika diteruskan akan membuat kecenderungan pola pikir eksklusif yang ada dalam agama yang sudah diyakini oleh masing-masing pemeluk agama. ${ }^{139}$ Seperti adanya potensi konstruktif agama, yang akan berkembang jika setiap umat manusia menjunjung tinggi nilai toleransi. Karena toleransi membuat kita bisa bersikap menahan diri untuk halhal kecil yang bisa memunculkan konflik. Sebaliknya, potensi destruktif agama bisa terjadi, jika warga negara ini, tidak menerapkan sikap toleransi, tidak menciptakan kerukunan, serta yang parah, menganggap agamanya sendirilah yang benar. ${ }^{140}$

Adapun kaitannya dengan itu semua adalah bagaimana menciptakan hidup rukun antar umat beragama serta terus tertanam dalam hati dan perilaku tentang toleransi. Jalan yang harus ditempuh untuk mencapai kehidupan yang lebih damai, serta terawatnya sikap toleransi, yakni dengan melakukan dialog. Di mana dialog, memiliki konsep pemikiran dasar yang nantinya digunakan dalam menyelesaikan persoalan yang biasa terjadi dalam kehidupan sehari-hari. Baik antar individu atau kelompok. ${ }^{141}$ Mengingat Indonesia adalah sebuah negara pluralis. Yang di dalamnya banyak terdapat keragaman, mulai dari suku, adat, budaya, bahasa, serta agama. ${ }^{142}$ Kerukunan menjadi kunci utama keutuhan bangsa ini.

Toleransi, merupakan sikap yang harus tertanam pada setiap umat manusia, yang mana toleransi juga merupakan bentuk akomodasi dalam interaksi sosial. ${ }^{43}$ Bahwa manusia terlepas apa agama mereka, pasti akan hidup berbaur antar satu dengan yang lainnya. Jadi penting untuk menjaga keharmonisan agar tidak mudah terbawa emosi yang menyebabkan terjadinya perpecahan.

Dari penuturan diatas, solusi lain yang bisa dilakukan yakni dengan melakukan dialog antar sesama pemeluk agama, agar agama tidak lagi di maknai sebagai ajang menebar kebencian dan saling menghina kepada sesama. Karena jauh lebih dari itu, agama harusnya menjadi sebuah kekuatan guna perkembangan peradaban di bumi. Dalam artikel ini penulis akan membahas tentang bagaimana dialog yang terjadi antar umat beragama sehingga dalam dialog itu mampu menjadi piranti (perantara) dalam menumbuhkan sikap toleransi antar sesama umat beragama.

\section{Dialog Antar Umat Beragama}

Dialog antar umat beragama di Indonesia dalam buku yang ditulis Banawiratma, Zainal Abidin Bagir, serta kawan-kawannya, merujuk pada dialog yang dimulai sekitar tahun 1969. Di mana Prof. Mukti Ali pada 1970, di Ajaltoun, Libanon, pada saat Sidang Dewan Gereja Sedunia mengadakan konsultasi mengenai dialog antar iman dan mengatakan, ${ }^{144}$

Dialog antara Islam dan Kristen memang baru dimulai pada 1969. Ini datang dari inisiatif saya sendiri, yang kemudian saya diskusikan dengan teman-teman Kristiani. Kemudian, pada November 1969 diadakanlah pertemuan pertama di sebuah Kolese Katolik, dan dihadiri oleh saya sendiri sebagai perwakilan dari Muslim, kemudian dari dua orang Katolik dan tiga orang dari Protestan. Selanjutnya, untuk pertemuan kedua pada bulan desember, saya menyampaikan sebuah pemikiran mengenai opini saya

\footnotetext{
139 Ismail Hasani dan Bonar Tigor Naipospos, Dari Radikalisme Menuju Terorisme, Studi Relasi dan Transformasi Organisasi Islam Radikal di jawa Tengah dan D.I. Yogyakarta (Jakarta: Pustaka Media, 2012), 76.

140 Alwi Shihab, Islam Inklusif; Menuju Sikap Terbuka dalam Beragama (Bandung: Mizan, 1997), 41.

141 Diakses dari bttp://eprints.walisongo.ac.id/3915/3/104311013 Bab2.pdf, pada 13 Desember 2018, pukul $07: 47$.

142 Zuly Qadir, Gerakan Sosial Islam: Manifesto Kaum Beriman (Yogyakarta: Pustaka Pelajar, 2009), 16.

143 Graham, C. Kinloch, Sociological Theory: Development and Major Paradigm (Bandung: Pustaka Setia, 2005), 35.

144 J.B. Banawiratma dkk., Dialog Antar umat Beragama: Gagasan dan Praktik di Indonesia (Jakarta: Mizan Publika, 2010), 3-4.
} 
tentang (perilaku) Vatikan terhadap umat non-Kristen, seperti Yahudi, para Muslim, dan yang lainnya, terkait posisi Paus, dan sebagainya.

Dalam pengertiannya, sebenarnya berbeda antara dialog antar agama dengan dialog antar umat beragama, walau perbedaannya sedikit. Jika dialog antar agama dipahami sebagai upaya bersama diantara beberapa penganut agama untuk saling memahami, dan dalam praktiknya dialog antar agama harus dilandasi kejujuran dan keterbukaan sebagai syarat penting untuk mencapai kesepakatan bersama. Sebagaimana diketahui, bahwa kerukunan umat beragama telah menjadi salah satu pondasi yang sangat kuat dalam menjaga kesatuan bangsa Indonesia. Kerukunan pun dimengerti sebagai kondisi di mana kehidupan sosial berjalan dengan damai, tentram, saling menunjukkan sikap toleransinya, saling menghormati, dan segala sikap yang mencerminkan nilai-nilai dalam pancasila. ${ }^{145}$ Karena sebenarnya, dialog antar agama merupakan rangkaian usaha diri sendiri untuk mencarikan suasana dalam hubungan antar umat beragama yang biasanya tak jarang muncul konflikkonflik antar sesama pemeluk agama. ${ }^{146}$ Sedangkan untuk dialog antar umat beragama itu seperti halnya dialog lintas iman, hanya saja dialog lintas iman hanya sebatas pertemuan orang beda keyakinan, dan soal pembahasan lebih bebas dan tak membahas hal-hal yang terlampau serius. Kalau dialog antar umat beragama, pertama-tama dilihat dari bawah, yakni dari perjumpaan dalam kehidupan sehari -hari. Maksudnya, dialog yang berkembang dari bawah itu digambarkan dengan tujuh dataran yang memiliki hubungan antara satu dengan yang lainnya. Mengingat saat berdialog dapat dilakukan dengan melihat waktu dan kondisi tertentu. Adapun ketujuh langkah itu, seperti; dialog kehidupan, analisis sosial \& refleksi etis kontekstual, studi tentang tradisi-tradisi dalam agama individu itu, dialog antar umat beragama (berbagi tentang keimanan sebatas pengalaman), dialog antar umat beragama (berdiskusi tentang teologi dengan umat dari agama lainnya), dialog aksi, dialog intra agama. ${ }^{147}$ Terlihat dari keduanya, bahwa dialog antar umat beragama lebih mengekrucut dan lebih dalam lagi pengertiannya dari dialog antar agama.

Dialog antar umat beragama pun, bukan tanpa persoalan. Karena pasti di dalamnya membahas hal-hal yang mencakup keragamanan peradaban. Dialog antar umat beragama merupakan sarana yang paling mudah dalam menghadapi konflik-konflik antar umat beragama. ${ }^{148}$

Di Indonesia pernah ada perselisihan antar umat beragama, tepatnya semenjak masa Orde Baru, di mana hanya lima agama yang resmi diakui oleh pemerintah. Hal tersebut menyebabkan masyarakat yang tidak menganut lima agama resmi itu, serentak banyak yang masuk ke agama-agama yang tersedia, dengan tujuan hanya agar tidak dituduh sebagai komunis. Juga sekitar tahun 1960, umat Islam dan Kristen sempat mengalami ketidakharmonisan dalam hubungan mereka karena isu-isu tentang adanya kristenisasi yang beredar. ${ }^{149}$ Kemudian, ada lagi peristiwa yang terjadi pada 1 Oktober 1967 di Makassar, yakni ketika sebuah gereja dilempari sebuah batu-batu. Hal tersebut terjadi karena seorang

\footnotetext{
145 Departemen Agama RI, Bingkai Kerukunan Umat Beragama di Indonesia (Jakarta: Balitbang Agama Proyek Peningkatan Kerukunan Hidup Umat Beragama di Indonesia, 1997), 8 \& 20.

146 Afif Rifa'I, Dealektika Pemikiran dalam Dialog Antar Umat Beragama: Studi Kasus Forum Persaudaraan Umat Beriman (FPUB) DI. Yogyakarta, Jurnal Pemberdayaan Masyarakat, Volume 1, Nomor 1, (2017): 91.

${ }_{147}^{14 . B . ~ B a n a w i r a t m a ~ d k k ., ~ D i a l o g ~ A n t a r ~ U m a t ~ B e r a g a m a . . ., ~} 8$.

148 Ani Ayu Sintiyani dan Siti Maftuhah, Harapan dan Tantangan Dialog Antar Umat Beragama, Jurusan Perbandingan Agama, Fakultas Ushuluddin dan Filsafat (Bandung: Universitas Islam Sunan Gunung Djati, 2013), 5. Diakses dari http://www.academia.edu/5367600/Dialog Antar Umat Beragama, pada 10 Desember 2018, pukul 18:36.

149 E. Armada Riyanto, Dialog Interreligious: Historisitas, Tesis, Pergumulan, Wajah (Yogyakarta: Kanisius, 2010), 375.
}

62 | Imas Setiyawan, - Dialog Antar Umat Beragama Sebagai Piranti Menumbuhkan Sikap Toleransi 
pendeta Kristen Protestan menghina Nabi Muhammad SAW, dengan mengatakan bahwa Nabi Muhammad adalah seorang pezina, dan seorang yang tidak pandai, karena bagaimana mungkin seorang nabi tidak bisa menulis dan membaca. ${ }^{150}$ Pun alasan lain mudahnya tersulut emosi antar umat beragama jika merujuk pada teori konflik George Simmel yang telah dikutip oleh Ritzer dan Goodman (2003), konflik terjadi karena antar manusia itu mempunyai kekuatan emosional. ${ }^{151}$ Sehingga, mudah terbawa perasaan pada isu-isu yang menyangkut keyakinannya.

Dari isu-isu yang beredar serta peristiwa tersebut, pemerintah akhirnya mengadakan musyawarah antar agama pada 30 November 1967 di Jakarta. Dipimpin oleh K.H.M. Dachlan sebagai menteri agama, serta dihadiri sekitar 20 tokoh dari agama Islam, Protestan, dan Katolik. Pada saat musyawarah berlangsung, Soeharto yang saat itu menjadi presiden menjelaskan dalam pidatonya, bahwa tidak ada satu kelompok umat beragama pun yang boleh mengajak umat beragama lain untuk mengikuti agama mereka. Namun, pertemuan yang dilakukan saat itu belum menemukan titik terang. ${ }^{152}$

Akhirnya, pemerintah membuat sebuah proyek guna terciptanya kehidupan damai di dunia. Proyek tersebut dinamakan "proyek kerukunan antar umat beragama". Pada saat itu, proyek yang dibangun pemerintah masih dalam lingkup para pemimpin-pemimpin umat beragama saja serta menyusun aturan-aturan guna menata bagaimana agar hubungan antar umat beragama bisa kembali harmonis. Hingga pada akhirnya, proyek yang dibangun oleh pemerintah tersebut semakin mengalami perkembangan dan mulai terorganisir dengan baik. ${ }^{153}$ Tidak hanya itu, pemerintah juga menambah gagasannya, yakni dengan membuat sebuah piagam dengan pernyataan bersama berupa tanda tangan yang isinya menerima anjuran Presiden terkait kebebasan beragama agar yang sudah meyakini suatu agama tidak boleh dijadikan korban propaganda oleh penganut agama lainnya. ${ }^{154} \mathrm{Hal}$ tersebut ada dalam surat keputusan bersama (No. 01/BER/MDN-MAG/1969) yang berisi pelaksanaan tugas aparatur pemerintahan untuk menjamin ketertiban dan kelancaran pelaksanaan pengembangan dan ibadah agama oleh para pemeluknya. ${ }^{155}$

Untuk itu, dalam dialog yang terjadi antar umat beragama diperlukan adanya sikap saling terbuka untuk bersedia mengutarakan pandangan yang dimiliki oleh masing-masing individu atau kelompok secara tepat, serta saat berkomunikasi harus benar-benar mendengarkan apa yang disampaikan oleh lawan bicara dengan baik. Karena dialog itu proses untuk membangun rasa saling percaya antar sesama teman bicara. ${ }^{156}$ Bukan hanya pertemuan antara dua individu atau kelompok yang berbeda saja, tetapi juga buah dari kesadaran pada diri sendiri tentang makna dari kemanusiaan.

Dialog antar umat beragama menurut H. Kasno Sudaryanto terbagi menjadi empat jenis. Pertama, dialog kehidupan; menjadi aktual dalam kehidupan bersama apabila satu dengan yang lainnya saling menghormati, menghargai, dan menerima perbedaan orang lain. Kedua, dialog aksi atau karya; usaha untuk melakukan kegiatan sosial yang tujuannya

\footnotetext{
${ }^{150}$ Umar Hasyim, Toleransi dan Kemerdekaan Beragama dalam Islam Sebagai Dasar Menuju Dialog dan Kerukunan Antar Agama (Surabaya: Bina Ilmu, 1979), 314.

151 Nazmudin, Kerukunan dan Toleransi Antar Umat Beragama dalam Membangun Keutuhan Negara Kesatuan Republik Indonesia (NKRI), Journal of Government and Civil Society, Volume 1, Nomor 1, April 2017), 25.

152 Sudjangi, Pembinaan Kerukunan Hidup Umat Beragama: 50 Tabun Kemerdekaan Republik Indonesia (Jakarta: Departemen Agama RI, 1995/1996), 43-52.

153 J.B Banawiratma dkk., Dialog Antar Umat Beragama.., 37.

154 Umar Hasyim, Toleransi dan Kemerdekaan..., 330.

155 J.B Banawiratma, 40.

156 Olaf, Scumman, "Some Reflection on the Meaning and Aims of Interfaith Dialogue", in Dialogue and Beyond: Christians and Muslims, Together on the Way (Switzerland: The Lutheran World Moderation, 2003), 13-14.
} 
membantu oranglain tanpa melihat latar belakang agamanya. Ketiga, dialog pemahaman religius; kegiatan yang di mana masing-masing pemeluk agama menceritakan pengalaman keagamaannya. Keempat, dialog teologi; menjelaskan tentang bagiamana ajaran atau keimanan agama masing-masing, yang dimaksudkan agar masing-masing pihak mengerti dan bisa saling memahami perbedaan yang ada. ${ }^{157}$

Dialog antar umat beragama dapat terjadi dan terus berjalan dengan baik apabila semua pihak yang terlibat melakukannya dengan niat yang baik, tulus, bersungguh-sungguh, terbuka, tidak mudah menghujat satu dengan lainnya, pun menuduh. Dialog antar umat beragama ataupun antar agama harus berjalan dengan seimbang. Karena dialog tidak akan berlangsung ketika salah satu pihak merasa lebih benar.

\section{Toleransi}

Toleransi berasal dari bahasa latin "tolerantia" yang artinya kelonggaran, kelembutan hati, kesabaran, atau bisa juga keringanan. ${ }^{158}$ Kalau dari bahasa Inggris "Tolerance" yang berarti membiarkan. ${ }^{159}$ Kemudian, jika diartikan dalam bahasa Arab, sama dengan makna tasamuh dari lafadz samaha (سمح), yang memiliki arti ampun, lapang dada, dan maaf. 160 Adapun toleransi memang selalu mengacu pada sikap yang terbuka, sabar, saling tolong menolong. Toleransi pun selalu mengarah ke konteks yang positif, contohnya, saling menghargai dan memberi kebebasan siapa saja untuk memilih apa yang dia yakini. Mengingat Tuhan menciptakan berbagai macam agama, bukan tanpa tujuan. Melainkan untuk kepentingan seluruh umat manusia. Disesuaikan dengan manusianya, waktu dan tempat. Ajaran-ajaran dalam agama dimaksudkan sebagai jalan, namun bukan diartikan Tuhan itu sendiri. Laiknya zat yang sama, air memiliki penyebutan berbeda sesuai wilayah. Ada yang menyebutnya water, eau, aqua, ada lagi pani. Kemudian, istilah tentang Tuhan bisa berupa God, Allah SWT, Yehovah, juga Brahman. ${ }^{161}$

Bahkan dalam sejarah filosofis, Nurcholis mengatakan bahwa siapa saja yang hanya suka melihat perbedaan-perbedaan yang ada sebagai sesuatu yang sangat penting, maka orang itu diibaratkan berada dalam sebuah lingkaran namun berada dibagian pinggiran. Namun, barangsiapa yang mampu membuka tabir the heart of religion atau the religion of heart, maka dia akan berada dalam lingkaran itu dan bisa bertemu dengan semua umat beragama serta membuat seluruh umat beragama bisa bertemu. Jadi biar Tuhan menjadi sesuatu yang tersembunyi, hanya ada dalam hati kita paling dalam. ${ }^{162}$

Toleransi adalah kemampuan memahami dan menerima adanya perbedaan yang ada. Dalam era modern, pertemuan antar berbagai agama dan lintas iman di dunia semakin cepat dan mudah hingga menyebabkan mudahnya saling mengenal satu dengan yang lainnya.

Toleransi menurut Sullivian, Pierson, dan Marcus yang sudah dikutip Saiful Mujani, dalam bukunya Islam, Budaya Demokrasi, dan Partisipasi Politik di Indonesia Pasca-Orde

\footnotetext{
157 Arian Wanti Paluta, Makalab: Perwujudan Hidup Beragama (Surabaya: Universitas Katolik Widya Mandala Surabaya, 2014), 1-2. Diakses dari http://wmw.academia.edu/8213477/perwujudan_bid-up_beragama, pada 13 Desember 2018, pukul 06:23.

${ }^{158}$ Hornby AS, Oxford Advanced Learner's Dictionary (Oxford: University Printing House, 1995), 67.

159 Tim Penyusun, Kamus Bahasa Indonesia (Jakarta: Pusat Bahasa Departemen Pendidikan Nasional, 2008), 1538.

160 Ahmad Warson Munawir, Kamus Arab-Indonesia Al-Munawir (Yogyakarta : Balai Pustaka Progresif, 2002), 1098.

161 Huston Smith, Agama-agama Manusia (Jakarta: Yayasan Obor Indonesia, 1991), 102-103.

162 Muzakkir, Toleransi Beragama dan Mahabbah dalam Perspektif Sufi, TEOLOGLA, Nomor 1, Volume 23, (Januari 2012): 129.
}

64 Imas Setiyawan, - Dialog Antar Umat Beragama Sebagai Piranti Menumbuhkan Sikap Toleransi 
Baru, menyatakan bahwa toleransi itu sebuah kesediaan untuk menghargai, menerima, juga menghormati segala sesuatu yang ditolak atau ditentang oleh seseorang. ${ }^{163}$

Toleransi juga bisa dikatakan berteman dalam perbedaan. Karena, dalam suatu negara, pasti ada di mana keyakinan yang beragam, tradisi, asal daerah, dan beberapa lainnya, dan masyarakat dalam negara manapun, memiliki prinsipnya masing-masing, yang bisa jadi berbeda. Tapi harus memahami pilihan maupun prinsip orang lain.

Adapun toleransi yang berkaitan dengan agama, di dalamnya membahas tentang masalah-masalah keyakinan, dalam artian saling memberi kebebasan dalam memilih apa yang individu atau kelompok itu yakini, serta memberi penghormatan mengenai ibadah serta penerapan ajaran-ajaran keagamaan yang sudah dianut. ${ }^{164}$ Karena pada hakikatnya, agama itu sebenarnya satu. Tetapi, menjadi beragam dan bersifat plural karena sudah diturunkan di bumi. Meskipun begitu, semua agama-agama yang ada dibumi, tetap membawa manusia kepada Tuhan. ${ }^{165}$

Toleransi dalam hal beragama pun memiliki dua tipe. Pertama, toleransi yang pasif, sikap menerima perbedaan sebagai hal yang factual. Kedua, toleransi aktif; bagaimana sikap seseorang itu dalam berhubungan dengan masyarakat lainnya, mengingat dalam dunia ini banyak terdapat keragaman serta perbedaan. Hakikat toleransi pun hidup secara damai, saling berdampingan serta saling menghormati. ${ }^{166}$

Ketika kita telah melakukan sikap toleransi dengan penuh kesadaran, maka akan terlahirlah sikap inklusif antar umat bergama. Yang di mana kita tetap meyakini bahwa agama kita yang benar, namun tetap membiarkan mereka memiliki ruangnya sendiri tentang agama yang telah diyakini. ${ }^{167} \mathrm{Jadi}$, toleransi cukup untuk kita menghormati mereka yang berbeda, dan tidak mengganggu kehidupan mereka.

\section{Dialog dan Toleransi dalam Perspektif Agama-Agama}

Dialog tidak hanya soal keimanan, tapi juga membawa nama institusi sosial. Karena dialog yang dilakukan lintas agama. Martin Forward, mengemukakan pendapatnya tentang dialog:168

Dialog akan dimulai ketika orang-orang telah bertemu. Pengertian dialog bergantung pada kepercayaan timbal balik. Dan melalui dialoglah kemungkinan-kemungkinan tentang rasa ingin berbagi, serta saling melayani.

Dialog menjadi sarana untuk kesaksian yang otentik.

Mamoud Ayoub dalam buku yang ditulis Charles Fletcher, berpendapat bahwa konsep dialog lebih menukarkan agama (conversion) seseorang, dikarenakan dalam dialog turut membina persamaan pemahaman yang lebih baik sekaligus sama-sama mengekalkan suatu ciri keagamaan. ${ }^{169}$

Tentang dialog antar agama dapat dipelajari hal-hal seperti berikut: pertama, adanya upaya untuk bersikap terbuka perihal keimanan. Kedua, bisa bersikap lebih demokratis,

163 Saiful Mujani, Muslim demokrat: Islam, Budaya Demokerasi, dan Partisipasi Politik di Indonesia Pasca-Orde Baru (Jakarta: Gramedia Pustaka Utama, 2007), 162.

164 J. Cassanova, Public Religions In The Modern World (Chicago: University Press, 2008), 87.

165 Mula Shadra, al-Hikmah al-Muta Aliyah fi Asfar al-Arba'ah al-'Aqliyyah, Volume 3 (Beirut: Dar Ihya' alTurath al-'Arabi, 1981), 278.

166 Casram, Membangun Sikap Toleransi Beragama Dalam Masyarakat Plural, Ilmiah Agama dan Sosial Budaya, Volume 1, Nomor 2 (Juli 2016): 191.

167 Casram, Membangun Sikap Toleransi Beragama..., 188.

168 J.B. Banawiratma dkk., Dialog Antar umat Beragama..., 7.

${ }_{169}$ Charles Fletcher D, Isma'il Al-Faruqi (1921-1986) and Interfaith Dialogue: The Man, the Cholar The Participant, Thesis Doctor of Philosophy, The Institute of Islamic Studies, Mc Gill University, 295. 
maksudnya adanya dialog merupakan usaha manusia dalam memandang mitra dialog secara seimbang atau setara. Ketiga, kesediaan untuk mamahami sesuatu dari sudut padang mitra dialog, tanpa perlu menyetujui sudut pandangnya. Keempat, dialog tidak digunakan untuk ajang perdebatan yang di mana memandang sesuatu hanya dari satu sudut pandang. Misalnya, hanya dari sudut pandang orang Islam. ${ }^{170}$ Mengingat agama bisa menjadi kekuatan guna memerjuangkan kemanusiaan yang dapat membimbing, serta membuat umat beragama menuju ke kehidupan yang dialogis. ${ }^{171}$

Dialog antar umat beragama juga memiliki beberapa model, seperti dialog parlementer (dialog ini biasa dihadiri oleh hampir ratusan peserta), contohnya; World Confrence on Religion and Peace pernah menyelenggarakan dialog antar umat beragama pada tahun 1980-1990an. Kemudian, dialog kelembagaan (wakil-wakil institusional dari berbagai organisasi agama). Dialog ini dilaksanakan untuk membicarakan jika ada masalahmasalah mendesak yang sedang muncul dikalangan umat beda agama. Ketiga, dialog teologi (pertemuan-pertemuan regular dan non-reguler). Biasanya, dialog ini membahas persoalan teologis dan filosofis. Keempat, dialog dalam masyarakat (lebih membahas hal-hal yang praktis). Yang terakhir, dialog kerohanian; tujuannya untuk memperdalam iman seseorang atau suatu kelompok pemeluk suatu agama. ${ }^{172}$

Untuk itu, penting sekali seseorang bagaimana berperilaku yang baik terhadap umat beragama lain, agar tidak menimbulkan permasalahan lagi yang bisa merusak kerukunan antar sesama pemeluk agama. Serta penting bagi kita untuk memahami perbedaan dialog antar umat beragama, dialog antar agama, macam-macam dari dialog, dan dialog-dialog menurut persepktif agama-agama resmi yang ada di Indonesia ini.

\section{Menurut Agama Hindu}

Dalam ajaran agama Hindu, perihal etika, budi pekerti, rasa cinta kasih, telah banyak sekali diajarkan. Umat Hindu meyakini bahwa apa pun jalan yang sudah ditempuh oleh setiap manusia untuk beribadah pada Tuhan itu benar, asalkan tidak bertentangan dengan nilai-nilai kemanusiaan yang ada. Hal ini sudah ada juga dalam kitab Bhagawadgita IV.11:

"Apa pun jalan yang telah ditempuh manusia untuk mendekati-Ku, Aku akan menerimanya. Manusia dari manapun yang telah mengikuti jalan-Ku, Oh Partha." ${ }^{173}$

Agama Hindu, sebenarnya juga menyembah Tuhan Yang Esa, yakni Sang Hyang Widhi. Hanya saja, penyebutan tentang Tuhan dalam agama Hindu, berbeda-beda. Seperti dalam kitab Rgveda I.164.46, "Tuhan Yang Maha Agung adalah Tunggal. Mereka yang bijak memanggilNya dengan sebutan yang berbeda-beda,..” 174

Kemudian, perihal toleransi. Umat Hindu menganggap toleransi bukan sekadar ajaran untuk melakukan kebaikan. Tapi memang keyakinan yang ada dalam ajaran agama Hindu. Bahkan, umat Hindu menjunjung toleransi sampai-sampai membolehkan umat Hindu lainnya untuk pindah agama, tanpa ada istilah seperti Islam, "murtad". Karena dalam ajaran Hindu mempercayai, bahwa siapa saja yang awalnya telah memercayai agama Hindu,

\footnotetext{
${ }^{170}$ Badru, D. Kateregegga, dan David W. Shenk, A Muslim and Chrisian Dialogue (terj.) Dialog Islam dan Kristen (Semarang: Pustaka Muria, 2007), 16.

171 Anas Aijudin, Mengelola Pluralisme Melalui Dialog Antar Agama (Sebuah Tinjauan Teoritik), SMaRT, Volume 3, Nomor 1, (Juni 2017): 123.

172 Zainudin Muhammad, Makalah: Pluralisme dan Dialog Antar Umat Beragama, Studia Philosophica et Theologica, Volume 5, Nomor 1 (Maret 2005): 10.

173 Bhagawadgita IV:11.

174 Rgveda I.164.46
}

66 | Imas Setiyawan, - Dialog Antar Umat Beragama Sebagai Piranti Menumbuhkan Sikap Toleransi 
suatu saat akan kembali pada ajaran Hindu. ${ }^{175}$ Manusia harus menjaga hidup rukun antar umat beragama, seperti dasar keyakinan umat Hindu, Catur Purusa Artha (Empat Tujuan Hidup Manusia). ${ }^{176}$

Dalam memandang tentang dialog antar agama maupun antar umat beragama, umat Hindu menyebutnya dengan sebutan tat twam "aku adalah kamu, dan kamu adalah aku." Pernyataan tersebut, ada dalam filsafat Hindu, yang di mana maknanya adalah mengajarkan umatnya untuk terus membangun hubungan persaudaraan dengan yang lainnya. Tuhan atau Dewa hadir pada setiap entitas alam semesta, termasuk manusia. Karenanya, menghormati, dan menghargai manusia berarti meyakini dan patuh pada Tuhan. ${ }^{177}$

\section{Menurut Agama Buddha}

Agama Buddha memiliki tiga ajaran pokok, yaitu Buddha, Dharma dan Sangha. Dalam ajaran agama Buddha tentang Dharma, ada yang namanya ajaran kosmologi, atau sebuah penciptaan dan pemeliharaan alam semesta yang sangat penting dalam dharma (kebenaran). ajaran tentang kosmologi tersebut, membuat manusia membuka matanya dalam artian, mencoba melihat dirinya sendiri agar bisa menarik benang merah dari ajaran Sang Buddha yang ditujukan untuk umatnya, yang di dapat melalui diskusi dan dialog-dialog yang sudah ada dalam dharma. ${ }^{178}$

Teori toleransi dalam agama Buddha, terdapat dalam Pancasila Buddhis yang berisi sila-sila sebagai pedoman hidup umat Buddha, agar senantiasa hidup damai dalam dunia. Dalam agama Buddha, Pancasila Buddhis merupakan aturan untuk umat Buddha yang berisi lima sila mengenai hal-hal yang tidak boleh dilakukan oleh umat Buddha berkaitan dengan tindakan-tindakan yang tercela. Pancasila Buddhis juga merupakan pedoman hidup bagi umat Buddha, terutama bagi upasaka ${ }^{179}$ dan upasika. ${ }^{180}$

Menurut Teja, dalam buku Sila dan Vinaya; sila merupakan kehendak manusia berupa ucapan, perbuatan, dan penghidupan yang benar. Sila juga merupakan awal yang penting untuk mencapai peningkatan batin yang luhur. Seperti dalam Samyutta Nikaya (V.143): "Apakah permulaan dari batin yang luhur? Sila yang sempurna kesuciannya". ${ }^{181}$

Adapun isi dari Pancasila Buddhis; pertama, Panatipata Veramani sikkhapadang samadiyami (kami bertekad melatih diri menghindari pembunuhan makhluk hidup), Maksudnya, setiap umat Buddha wajib untuk berbuat baik dan mencintai sesama makhluk hidup. Seperti, tidak membunuh manusia dan binatang, menyiksanya, serta tidak boleh menyakiti manusia maupun binatang. Kedua, Adinnadana veramani sikkha padang samadiyami (kami bertekad melatih diri menghindari, mengambil ataupun menggunakan barang yang

\footnotetext{
175 Pos Bali Online, diakses dari https:// www.posbali.id/dalam-bindu-toleransi-adalah-keyakinan/, pada 11 Desember 2018, pukul 17:49.

176 Cik Melati, Toleransi dalam Perspektif Agama Hindu, diakes dari https://www.scribd.com/doc/136750359/Toleransi-Dalam-Perspektif-Agama-Hindu, pada 11 Desember 2018, pukul 18:39.

177 Dion Remetwa, Dialog Antar Agama. Diakses dari http://dimasche.wordpress.com/2012/05/21/di-alog, pada 12 Desember 2018, pukul 23:07.

178 I Gusti Made Widya Sena, Konsep Kosmologi Dalam Perspektif Agama Buddha, Vidya Sambita Jurnal Penelitian, 111. Diakses dari http://sim.ihdn.ac.id/app-assets/repo/repo-dosen-101701123816-58.pdf, pada 9 Desember 2018, pukul 20:49.

179 Upasaka (Umat Buddha Laki-Laki) dan Upasika (Umat Buddha Perempuan), seseorang yang telah menyatakan diri bertekad melatih dirinya dengan sungguh-sungguh untuk melaksanakan sila-sila yang terdapat pada Pancasila Buddhis.

${ }^{180}$ Karsan \& Effendie, Pendidikan Agama Buddha dan Budi Pekerti (Jakarta: Kementerian Pendidikan dan Kebudayaan, 2017), 63.

181 Febrian Ariya Passaddhi, Sila dan Kebaikan, 2. Diakses dari http://www.academia.edu/6539607/PELAKSANAAN SILA DALAM AGAMA BUDDHA MENIMBULKAN KEBAIKAN BAGI DIRI SEN DIRI DAN ORANG LAIN, pada 04 Desember 2018, pukul 20:37.
} 
bukan milik kami), pernyataan tersebut seperti tidak mencuri, korupsi, taruhan, bermain judi, dan yang sejenisnya. ${ }^{182}$ Ketiga, Kamesumicchacara Veramani sikkhapadam samadiyami (Kami bertekad melatih diri menghindari perbuatan asusila), dianjurkan bagi seluruh umat Buddha untuk senantiasa menjaga dirinya selalu dalam keadaan suci, selalu waspada, dan dapat mengendalikan diri terlebih nafsunya. ${ }^{183}$ Keempat, Musavada Veramani sikekhapadam samadiyami (kami bertekad melatih diri menghindari perkataan yang tidak benar), jadi, umat Buddha dianjurkan untuk terus berkata baik, tidak boleh memfitnah orang, bergosip, memaki kepada sesama, dan mengeluarkan kata-kata kasar yang akhirnya dapat melukai orang lain. Kelima, Suramerayamaijapamadatthana Veramani sikhapadang samadiyami (kami bertekad melatih diri menghindari makanan dan minuman yang menimbulkan lemahnya kewaspadaan), umat Buddha juga dianjurkan untuk menghindari segala hal yang dapat merusak konsentrasi pun kewaspadaan dalam dirinya dengan cara meningkatkan konsentrasi saat bermeditasi. ${ }^{184}$

Dalam ajaran agama Buddha, mereka memiliki prinsip untuk selalu memuliakan Tuhan. juga makhluk hidup sebagaimana yang diterapkan dalam bhakti-puja di kehidupan sehari-hari. Seseorang harus rela jika sewaktu-waktu berkorban untuk orang lain, dan harus selalu memiliki sifat rendah hati, dan tidak egois.

Harold Coward mengemukakan pendapatnya tentang sikap Buddhisme kepada penganut agama lain dalam bukunya Pluralism in the World Religions, bahwa sikap seorang Buddhisme kepada orang lain berpacu pada prinsip toleransi kritis. ${ }^{185}$

Pada dasarnya, umat Buddha sangat menghormati seseorang yang memiliki perbedaan keyakinan dengan mereka. Bagi mereka, agama bukan jalan yang paling benar untuk mencapai pencerahan. Pandangan tersebut mirip dengan relativisme, yang menganggap semua agama benar dan sama, serta menuju pada tujuan yang sama. Hanya saja umat Buddha memiliki keyakinan bahwa mereka tetap menolak ada agama lain untuk bisa mengantar ke pencerahan. ${ }^{186}$

\section{Menurut Agama Islam}

Dalam agama Islam, toleransi bukan hanya kepada sesama manusia saja, tapi juga mencakup alam semesta, baik itu binatang, maupun lingkungan hidupnya. Definisi Islam dirumuskan dengan "Islam agama rahmatan lil'älamîn" (agama yang mengayomi seluruh alam), yang maknanya, umat Islam sadar bahwa adanya keragaman memang sudah kehendak dari yang Maha Kuasa dan tidak dapat disamakan, maka dari itu agama Islam menghadirkan sikap saling menghormati sebagai bentuk dialog dan toleransi dalam agama Islam. ${ }^{187} \mathrm{Hal}$ ini ada dalam al-Qur'an surah al-Baqarah 256:
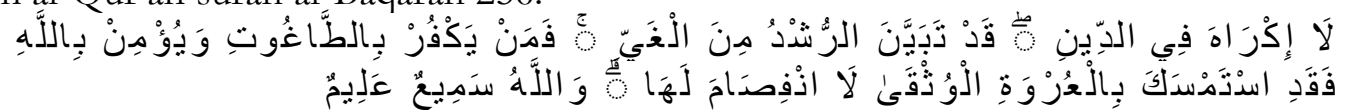

Artinya: Tidak ada paksaan untuk (memasuki) agama (Islam); sesungguhnya telah jelas jalan yang benar daripada jalan yang sesat. Karena itu barangsiapa yang ingkar kepada Thaghut dan beriman kepada Allah, maka sesungguhnya ia telah berpegang kepada buhul

\footnotetext{
182 Karsan \& Effendie, 64.

${ }^{183}$ Febrian Ariya Passaddhi, Sila dan Kebaikan, 3.

184 Ibid.

${ }^{185}$ Harold Coward, Pluralism in the World Religions A Short Introduction (Boston: One World-Publications, 2000), 127.

${ }^{186}$ Maufur, Pluralisme Agama dalam Budhisme, Universum, Volume 9, Nomor 2 (Juli 2015), 229.

187 Aslati, Toleransi Antar Umat Beragama Dalam Perspektif Islam (Suatu Tinjauan Historis), 2. Diakses dari bttps:/ / media.neliti.com/ media/publications/40259-ID-toleransi-antar-umat-beragama-dalam-perspektif-islam-suatutimjanan-historis.pdf, pada 04 Desember 2018, pukul 18:37.
}

68 | Imas Setiyawan, - Dialog Antar Umat Beragama Sebagai Piranti Menumbuhkan Sikap Toleransi 
tali yang amat kuat yang tidak akan putus. Dan Allah Maha Mendengar lagi Maha Mengetahui. ${ }^{188}$

Kemudian, dalam surah al-Mumtahanah ayat 8 juga dijelaskan bahwa seorang muslim harus selalu berbuat baik juga adil kepada sesama umat manusia, meskipun orang itu kafir. Hanya saja dengan syarat mereka yang bukan Islam tidak memerangi agama Islam.
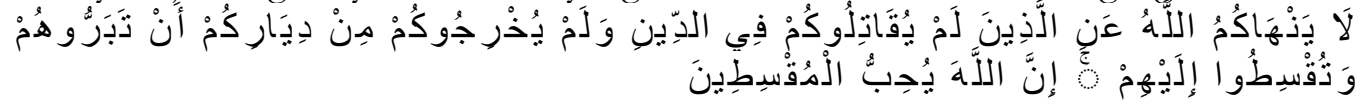

Artinya: Allah tidak melarang kamu untuk berbuat baik dan berlaku adil terhadap orang-orang yang tiada memerangimu karena agama dan tidak (pula) mengusir kamu dari negerimu. Sesungguhnya Allah menyukai orang-orang yang berlaku adil. ${ }^{189}$

Selain itu, ada pula ayat lain yang menjelaskan tentang perdamaian dan hak yang setara terhadap sesama pemeluk agama dalam surah al-Baqarah ayat 62:

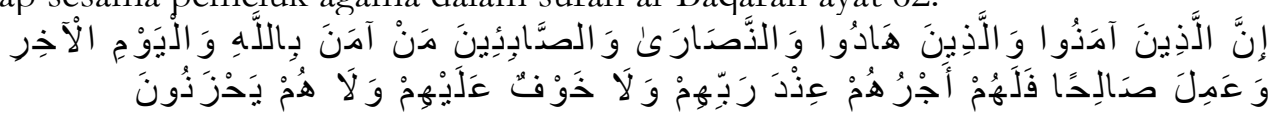

Artinya: Sesungguhnya orang-orang mukmin, orang-orang Yahudi, orang-orang Nasrani dan orang-orang Shabiin, siapa saja diantara mereka yang benar-benar beriman kepada Allah, di hari kemudian dan beramal saleh, mereka akan menerima pahala dari Tuhan mereka, tidak ada kekhawatiran kepada mereka, dan tidak (pula) mereka bersedih hati. ${ }^{190}$

Tafsir untuk ayat diatas menurut Said Aqil Siradj, jika di maknai secara tekstual, akan memberikan paandangan tentang keragamaan agama yang dipeluk oleh umat manusia dalam perspektif agama-agama lainnya. ${ }^{191}$ Ayat diatas juga mampu menghancurkan benteng-benteng antar agama yang biasanya dijadikan alasan untuk menimbulkan masalah terhadap umat beragama. Bahkan Allah SWT dalam ayat tersebut sudah jelas mengatakan tidak melihat seorang itu dari agama apa, asalkan dia beriman dan selalu beramal sholeh. ${ }^{192}$

Umat Islam memang tidak mengakui Yesus sebagai Allah, tapi tetap menghormatinya sebagai nabi. Umat Islam pun juga menghormati dan menganggap bahwa Maria atau Maryam itu tetap perawan. Dalam ajaran Islam juga sangat menjunjung kehidupan susila, dan patuh pada Allah, seperti selalu memanjatkan do'a, suka memberi atau bersedekah, serta puasa. ${ }^{193}$

Dalam Islam masih banyak lagi dalil-dalil yang menjelaskan tentang bagaimana seorang muslim jika harus bersikap dengan yang diluar agamanya. Tapi tidak bisa dipaparkan secara lengkap di sini. Dari apa yang sudah dipaparkan sangat jelas bahwa islam sangat menjunjung tinggi nilai toleransi antar sesama umat manusia.

Kemudian, agama Islam dalam memandang dialog telah meluas dikalangan para ulama' maupun ilmuan Islam lainnya. Yang pasti tidak lepas dari al-Quran dan hadits. Perbincangan antara ulama' dan ilmuan muslim tersebut, telah menghasilkan konsep dialog dalam perspektif Islam dari tiga sudut pandang. Pertama, dialog merujuk pada perdebatan. Kedua, dialog bisa menjadi sebuah dakwah. Ketiga, dialog merujuk pada bagaimana membina

\footnotetext{
188 Q.S. al-Baqarah [(2): 256]

189 Q.S. al-Mumtahanah [(60): 8]

190 Q.S. al-Baqarah [(2): 62]

191 Said Aqil Siradj, Islam Kebangsaan;Fiqib Demokratik Kaum Santri (Jakarta : Pustaka Ciganjur, 1999), 231.

192 Idrus Ruslan, Etika Islam Dan Semangat Pluralisme Agama Di Era Global, Al-AdYaN, Volume V, Nomor I, (Januari-Juni 2010): 8.

193 J.B. Banawiratma dkk., Dialog Antar umat Beragama..., 25-26. Lihat juga di "Pernyataan 'Nostra Aetate' tentang Hubungan gereja dengan Agama-agama Bukan Kristen" dalam Dokumen Konsili Vatikan II, 311312. Diakses dari http://katolisitas.org/dokumengereja/vatican-ii/dekrit-tentang-ekumenisme/, pada 04 Desember 2018, pukul 20:59.
} 
hubungan yang baik. ${ }^{194}$ Dalam al-Quran ada dasar perkataan dialog (hiwar) yang ada dalam al-Quran dan hadits, memiliki makna interaksi atau pertemuan antara dua pihak yang memiliki pandangan berbeda. ${ }^{195}$

\section{Menurut Agama Kristen}

Toleransi dalam agama Kristen pasti merujuk juga pada alkitab. Ajaran dalam agama Kristen mengajarkan tentang rasa kasih membuat seseorang itu lebih toleran. Kasih membuat seseorang dapat memahami makhluk lainnya. ${ }^{196}$ Dalam alkitab dijelaskan, "Teruslah seseorang itu bersabar terhadap manusia lainnya dan berilah ampun kepada sesama dengan hati yang lapang, bahkan jika memiliki alasan untuk mengeluh jika berkaitan dengan orang lain." 197

Arti toleransi lainnya dalam pandangan agama Kristen, yang pertama adalah bagaimana seorang umat kristiani harus bisa memanfaatkan waktu sebaik mungkin dan mengambil kesempatan yang ada untuk menjadi kristus. Maksudnya, karena hidup telah diatur oleh Allah. Allah akan memberikan izin pada seluruh umatnya untuk berinteraksi pada semua umat manusia, bahkan dari luar agamanya. Kristus di sini adalah bagaimana menjaga pandangan, hingga tetap tertuju pada Kristus, dan kunci untuk menjaga itu semua tergantung bagaimana Roh Kudus dalam mengarahkannya. Kedua, rasa taat kepada Allah dan firman-Nya harus lebih dalam daripada kepada manusia. Ketiga, harus megasihi orang lain seperti mengasihi dirinya sendiri. Seperti dalam alkitab, Yakobus 2:8, 198 "Jika kamu menjalankan hukum utama sesuai dengan yang ada di Kitab Suci, "Kasihilah sesama manusia, seperti kamu mengasihi dirimu sendiri, dan kamu telah melakukan hal yang benar". Jadi, setiap uma Kristiani wajib untuk selalu menebar kasih pada setiap orang tanpa syarat. Keempat, menyikapi dengan bijak tentang perbedaan pendapat. Mengingat Tuhan menciptakan manusia bermacam-macam karakter, juga pola pikir. Pasti antara satu dengan yang lainnya akan muncul perbedaan pendapat. Maka dari itu, diperlukan sekali sikap saling menghormati perbedaan yang ada, dan memahami pendapat masing-masing individu. Kelima, menghormati manusia lain dengan memberi kasih karunia. Kolose 4:6, ${ }^{199}$ "Biarlah perkataanmu selalu penuh kasih, dibumbui dengan garam, supaya kamu tahu bagaiama cara menjawab setiap manusia." Di sini dijelaskan bahwa bagaimana kemampuan diri sendiri dalam memperlakukan seseorang dengan hormat. ${ }^{200}$

Selain pandangan toleransi dari agama Kristen secara keseluruhan. Ada pula toleransi dalam pemahaman GKJW, bagi Gereja Kristen Jawi Wetan itu ibarat tubuh. Tentang bagaimana kita bisa makan, berjalan tanpa adanya tangan dan kaki. Mengingat toleransi memang telah ada dalam diri masing-masing umat manusia. Toleransi ada karena kita saling mengasihi. Toleransi yang dilakukan oleh umat GKJW tidak jauh berbeda dengan umat Islam. Bentuk toleransi yang telah dilakukan salah satunya yaitu "umat Kristen di GKJW mengadakan kunjungan ke beberapa pondok pesantren saat lebaran Idul

\footnotetext{
194 Ahmad Faizuddin dan Jaffary Awang, Dialog Antara Agama Menurut Perspektif Islam, Umran-International Journal of Islamic and Civilizational Studies, Volume 3, Nomor 2 (2016): 24.

195 Muhammad Sayyid al-Tantawi, Adab al-biwar fi Islam (Kaherah: Dar al-Nahd Misr, 1997), 4.

196 Saksi-saksi Yehuwa, diakses dari https://wmw.jw.org/id/publikasi/majalab/g201508/kata-alkitab-tentangtoleransi/, pada 8 Desember 2018, pukul 20:33.

197 Alkitab Kolose 3:13.

198 Alkitab Yakobus 2:8.

199 Alkitab Kolose 4:6.

200 Crystal Mcdowell, What Does the Bible Say About Tolerance? A Christian Study, diakses dari http:/ / www.whatchristianswanttoknow.com/what-does-the-bible-say-about-tolerance-a-christian-stydy/, pada 10 Desember 2018, pukul 16:37.
}

70 | Imas Setiyawan, - Dialog Antar Umat Beragama Sebagai Piranti Menumbuhkan Sikap Toleransi 
Fitri." Menurut Bapak Suwignjo selaku Pendeta Jemaat GKJW. ${ }^{201}$ Hal tersebut bertujuan untuk mengenal lebih dekat dan membangun rasa saling mengasihi terhadap antar umat beragama.

Selain itu, terdapat pula pernyataan dalam salah satu bagian yang ada pada Nostra Aetate ${ }^{202}$, pernyataan itu menyatakan bahwa Gereja adalah termasuk yang menghargai umat Islam, yakni menghormati bahwa menyembah Allah Yang Maha Esa, hidup dan berdaulat, penuh kasih sayang dan Yang Maha Kuasa, pencipta semesta, dan telah memberi firmanNya pada seluruh umat manusia. ${ }^{203}$ Tidak hanya itu, dalam Nostra Aetate ada lagi pernyataan tentang toleransi terhadap sesama umat manusia. Nostra Aetate Art. 1, menyatakan Gereja Katolik sangat percaya bahwa agama sangat penting dalam kehidupan. Yakni, pertama, semua agama telah menjelaskan di ajaranajarannya tentang awal mula kehidupan dan tujuan hidupnya, arti yang mendalam tentang kematian, hakikat sakit dan penderitaan atau dalam Islam itu cobaan, dan berbagai rahasiarahasia kehidupan lainnya. Kedua, semua agama sama-sama menuju pada Tuhan. Melalui ajaran-ajaran yang ada dalam agama, manusia sudah diberi gambaran yang jelas tentang beberapa pertanyaan tersebut. 204

Kemudian, dialog bagi orang Kristen itu berisi “pesan Kristus di kayu Salib.” Jadi sebuah dialog itu memberitakan tentang kebenaran, ketaatan iman umat kristiani. Dialog bagi orang Kristen bukan ajang untuk berdebat, tapi saling berpendapat menurut perspektif diri sendiri. Jadi, dialog itu saling berbagi "sharing" tentang keimanan, kasih sayang, juga perlunya sikap saling mendengar, mendiskusikan, dan mempelajari. 205

Dalam ajaran Kristen, ada yang namanya dialog "agaphe" atau kasih Allah. Merupakan sebuah ajaran dari Yesus untuk mengharuskan umatnya hidup rukun di tengahtengah masyarakat, baik itu berkomunikasi, saling tolong menolong, serta memberi kasih pada semua orang. Yesus mengajarkan untuk mengasihi siapapun sekalipun itu bukan dari agama Kristen. ${ }^{206}$

Menurut Romo Ilidius Yosef Sumarno, atau yang akrab disapa Romo Sumarno, seorang pendeta dari Katolik, dialog jika dilihat dari perspektif Katolik merupakan sebuah keterbukaan antar sesama, yang dimaksudkan agar di dalam suatu hubungan antar umat beragama itu menjadi baik, indah, dan berguna. Dialog juga melatih diri agar menjadi pribadi yang lebih dewasa. ${ }^{207}$

\section{Menurut Agama Khonghucu}

Ajaran yang ada dalam agama khonghucu, menekankan adanya moral atau etika termasuk toleransi. Bagi umat Konghuchu etika menempati posisi yang sangat sentral

\footnotetext{
201 Suwignjo, Wawancara, Surabaya, 10 Desember 2018.

${ }^{202}$ Nostra Aetate, salah satu dokumen dari Konsili Vatikan Kedua. Berisi pernyataan tentang Hubungan Gereja dengan Agama-Agama diluar Kristen.

203 J.B. Banawiratma dkk., Dialog Antar umat Beragama..., 25-26. Lihat juga di "Pernyataan 'Nostra Aetate' tentang Hubungan gereja dengan Agama-agama Bukan Kristen" dalam Dokumen Konsili Vatikan II, 311312. Diakses dari http://katolisitas.org/dokumengereja/vatican-ii/dekrit-tentang-ekumenisme/, pada 04 Desember 2018, pukul 20:59.

204 Daruma, 4 Nostra Aetate Art 1 Gereja Katolik Memandang, diakses dari bttps://wmw.coursehero.com/file/p1 qo5mp/4-Nostra-Aetate-Art-1-Gereja-Katolik-memandang-pentingnya-agama-dalam-kebidup-an/, $\quad$ pada 8 Desember 2018, pukul 20:14.

205 Yayasan Lembaga Sabda, Dialog Kebenaran Agaphe, diakes dari https://alkitab.sabda.org/resource.php?topic=1011 \&ores=jpz, pada 10 Desember 2018, pukul 17:48.

207 Ilidius Yosef Sumarno, Wawancara, 10 Desember 2018.
} 
dalam semua aspek kehidupan umat konghuchu, karena nabi konghuchu selalu mengarahkan kepada etika yang dikembangkan oleh kaum bijak kuno (nabi dan raja suci). ${ }^{208}$

Untuk itu, manusia harus menjalankan etika dengan menggunakan tata cara dan kebiasaan yang sebelumnya telah di ajarkan oleh para leluhur. Adapun kebajikan utama yang harus dilakukan; menjalankan Yi, yaitu perikeadilan atau keluhuran, serta Jen/Ren perikemanusiaan atau cinta kasih. ${ }^{209}$ Pertama, Yin; hakikat formal yang merupakan kewajiban manusia kepada sesama untuk selalu berbuat kebaikan. Sedangkan perikemanusian merupakan hakikat material dan bersifat lebih kongkret. Yang maksudnya, mengasihi manusia. Intinya, mengutamakan sikap tenggang rasa..10 Dalam kitab Su Si dijelaskan:

"Jangan melakukan sesuatu kepada orang lain, jika kamu tidak ingin orang lain melakukannya kepadamu." ${ }^{211}$ (Lun Gi XV: 24)

Ayat tersebut merupakan pondasi dasar ajaran persaudaraan dalam agama Khonghucu. Serta mengajarkan bahwa manusia memiliki potensi untuk mejadi baik karena pada dasarnya manusia memang sudah baik dari hasil pendidikan moral. ${ }^{212}$

Secara keseluruhan, inti ajaran agama Konghucu ialah setia dan tepaselira. Melaksanakan tugs kewajiban dengan sepenuh hati dan sekuat tenaga itulah yang dimaksudkan dengan setia. Tidak melakukan suatu perbuatan yang mengakibatkan hal tersebut berbalik arah pada diri sendiri, dinamakan tepaselira. Agama khonghucu telah mengajarkan bahwa kesusilaan merupakan pokok perilaku manusia. Tujuan terakhirnya, membentuk manusia susilawan (Kuncu/Chun Tzu). ${ }^{213}$

Dalam pemahaman agama Khonghucu tentang dialog, ajaran ini tidak membatasi pada kelompoknya saja. Tetapi, umat Khonghucu boleh berinteraksi dengan pemeluk agama lainnya. Karena yang terpenting dari dialog, bagaimana harus mengukur tingkat kemampuan dan sejauh mana wawasannya. ${ }^{214} \mathrm{Hal}$ ini tersirat dalam kitab Khonghucu yang merupakan petunjuk dari Nabi Khonghucu perihal dialog:

"Seorang yang pengetahuannya sudah melampaui tingkat pertengahan, boleh diajak membicarakan hal-hal yang lebih berat, besar, atau tinggi, dan seseorang yang masih memiliki tingkat pengetahuan rendah, tidak boleh untuk diajak membicarakan hal-hal yang berat atau besar." 215

Dan untuk tafsiran tersebut, bahwa para tokoh agama sangat diperlukan dalam membina pengetahuan para umat dan menanamkan rasa pluralis dalam diri. ${ }^{216}$ Karena kerukunan akan tercipta apabila toleransi selalu terjaga.

\section{Dialog Sebagai Piranti untuk Menumbuhkan Sikap Toleransi}

\footnotetext{
208 Muh. Nahar Nawawi, Memahamahi Konghucu Sebagai Agama (Jakarta: Gramedia Pustaka Utama, 2003), 43.

${ }^{209}$ Ibid., 44.

210 Diakses dari http://digilib.uin-suka.ac.id/2547/1/BAB\%20I\%2CV\%2C\%20DAFTAR\%20PUSTAKA.pdf, pada 12 Desember 2018, pukul 15:22.

${ }^{211}$ Kitab Su Si (Kitab Yang Empat), Kitab Suci Agama Konghucu Cet Ke X (Solo: Matakin, 2007), 280.

212 A. Singgit Basuki, Sejarah, Etika dan Teologi Agama Khonghucu, Cet. I (Yogyakarta: suka Press, 2014), 49.

213 Oei King Liang, Pelajaran Praktis Agama Konghucu Untuk Sekolah Lanjutan, Cet ke 2 (Jakarta: Matakin, 1974), 31.

214 Ongky Setio, Pandangan Agama Khonghucu Mengenai Dialog Menuju Perdamaian Dunia. Diakses dari bttp:// www.spocjournal.com/ religi/81-pandangan-agama-khonghucu-mengenai-dialog-menuju-perda-maian-dunia.btml, pada 12 Desember 2018, pukul 22:43.

${ }^{215}$ Lun Gi Jilid VI: 21.

216 Ibid., pada 12 Desember 2018, pukul 22:43.
}

72 | Imas Setiyawan, - Dialog Antar Umat Beragama Sebagai Piranti Menumbuhkan Sikap Toleransi 
Saat berbicara tentang bagaiamana dialog dapat menjadi piranti untuk menumbuhkan sikap toleran. Sama halnya dengan berbicara tentang fungsi dan manfaat adanya dialog antar umat beragama. Rasa toleransi yang tumbuh dari hati dan diwujudkan dengan perilaku manusia-manusianya, merupakan suatu kewajiban yang harus selalu dirawat bersama-sama oleh rakyat Indonesia. Berbagai kepentingan, kondisi yang ada mengharuskan seseorang untuk memahami apa sebenarnya hakikat hidup yang rukun antar umat beragama. Mengingat dialog dan kerukunan antar umat beragama merupakan dua proses komunikasi yang dapat bernilai kerjasama sehingga tidak pernah dapat dipisahkan. Dikarenankan, dialog merupakan salah satu bagian dalam membangun kerukunan antar umat beragama. ${ }^{217}$

Fethullah Gülen seorang pegiat dialog antar agama dari Turki, menerangkan bahwa saat berada dalam ruang dialog, bukan ajang untuk mencari-cari perbedaan, namun persamaanlah yang nantinya harus ditemukan. Sebagai contoh, antara agama Islam dan Kristen memiliki beberapa kesamaaan. Seperti; kedua agama tersebut sama-sama bersifat monoteisme, sama-sama agama wahyu, dan masih ada beberapa lagi persamaan lainnya. ${ }^{218}$

Dialog juga bukan sebagai tujuan akhir, tapi sebuah proses untuk bisa melanjutkan ke tujuan selanjutnya. Dalam cakrawala holistik, keterlibatan setiap individu atau kelompok dalam kehidupan sosial, merupakan hal yang sangat penting. Mengingat dialog antar umat beragama bisa berlangsung, jika individu atau kelompok itu mau bekerja sama dan saling menghargai perbedaan. ${ }^{219}$

Karena ada dialog yang terjadi antar umat beragama, terciptalah kehidupan yang damai. Seperti, menumbuhkan kembali sikap terbuka antar sesama pemeluk agama yang akhirnya bisa memulai kerjasama kembali demi kepentingan bersama. ${ }^{220}$ Untuk membuat seseorang lebih mengenal orang lain yang bisa menimbulkan rasa peduli antar sesama, dapat menciptakan rasa damai ditengah-tengah masyarakat, dapat saling menjamin kerukunan akan terus berlangsung antar umat beragama, serta agar terciptanya rasa ingin menolong kepada sesama yang masih perlu diberi contoh tentang arti kemanusiaan. ${ }^{221}$

Dialog antar umat beragama adalah usaha, di mana membuat teman bicara merasa nyaman, dan merasa "di rumah". Bagaimana membangun rasa saling menghargai dikala banyak perbedaan yang ada, merawat sebuah hubungan agar tetap bisa bersama, dan bisa menghancurkan pikiran-pikiran atau prasangka buruk tentang anarkisme, ataupun krisis bumi. ${ }^{222}$

Dampak atau manfaat lainnya terkait dengan adanya dialog antar umat beragama, bisa dilihat secara intern maupun ekstern. Jika itu dari segi intern, setiap pemeluk agama pasti akan memiliki kemampuan lebih dalam menghayati keimanannya dan lebih giat melakukan apa yang ada dalam ajaran agamanya. Kemudian, dari segi ekstern; setiap individu pemeluk suatu agama, akan lebih menghargai, memahami, keberadaan agama

\footnotetext{
${ }^{217}$ Khotimah, Dialog dan Kerukunan Antar Umat Beragama, Jurnal Ushuluddin, Volume XVII, Nomor 2, (Juli 2011): 214.

218 A. Rizqon Khamami, Dialog antar iman dalam Perspektif Fethullah Gülen, Religio, Volume 2, Nomor 1, (Maret 2012): 10.

219 J.B. Banawiratma dkk., Dialog Antar Umat Beragama..., 13.

220 Raihan Ghalib Muwaffaq dkk., Makalah: Hubungan Antar Agama Dialog Antar Umat Beragama (Band-ung: UIN Sunan Gunung Djati, 2018), 8. Diakses dari bttp://wmw.academia.edu/36765019/MAKALAH HUBUNGAN ANTAR AGAMA DIALOG ANTAR UMAT BERAGAMA, pada 10 Desember 2018, pukul 19:35.

${ }^{221}$ Ibid. Lihat juga di Paul F. Knitter, Satu Bumi Banyak, Agama (Jakarta: BPK Gunung Mulia, 2003), 51.

222 S. Wesley Ariarajah, Not Without My Neighbour, Tak Mungkin Tanpa Sesamaku: Isu-Isu dalam Relasi Antar-Iman, terj. Nico A. Likumahuwa (Jakarta: BPK Gunung Mulia, 2008), 14.
} 
lainnya. ${ }^{223}$ Jadi memang tepat, jika dialog menjadi sarana untuk menguatkan rasa empati pada pemeluk agama lainnya. Juga menjebatani pemikiran-pemikiran yang berbeda menjadi warna yang beragam jika dipertemukan ke dalam satu meja.

Dialog antar umat beragama dapat dikatakan telah menjadi perantara dalam menumbuhkan sikap toleran, ketika ada dua orang atau lebih saling bertukar pengalaman keagamaan, menjelaskan tentang ideologi mereka, mencari celah-celah persamaan diantara perbedaan yang ada. Yang di mana akan memberikan pemahaman lebih luas lagi hingga membuat seseorang itu terdorong untuk selalu bersikap toleran.

\section{Penutup}

Dari semua penjelasan yang sudah dipaparkan. Terlihat bahwa adanya dialog antar umat beragama sangat penting untuk kebutuhan hidup umat beriman dalam menghadapi perbedaan-perbedaan yang ada. Apalagi, dialog dan toleransi merupakan dua hal yang saling berkontribusi. Adanya dialog membuat manusia memiliki rasa empati, hingga akhirnya muncul sikap toleran pada perbedaan yang ada. Untuk melakukan dialog, setiap umat beragama harus memiliki prinsip-prinsip dasar di mana prinsip itu hadir dari ajaran yang ada dalam suatu agama atau pengalaman pribadi masing-masing individu.

Meski, setiap agama memiliki pandangan tersendiri tentang dialog sampai toleransi, akan tetapi dalil-dalil atau ayat-ayat yang ada di setiap kitab suci agama-agama memiliki penafsirannya sendiri yang walaupun perihal dialog juga toleransi pada hakikatnya sama, tetapi dalam praktiknya atau penerapannya, telah diatur masing-masing pada kitab suci setiap agama.

Mau tidak mau sebagai warga negara Indonesia, yang memiliki banyak keragaman. Harus merawat selalu sikap toleransi serta harus terus menjaga kerukunan antar umat beragama, karena berjumpa dengan orang atau kelompok dari agama lain sudah menjadi kebiasaan sehari-hari.

\section{Daftar Pustaka}

Aijudin, Anas. Mengelola Pluralisme Melalui Dialog Antar Agama (Sebuah Tinjauan Teoritik). SMaRT. Volume 3. Nomor 1. Juni 2017.

Al-Quran. Al-Mumtayaz. Bekasi: Cipta Bagus Segara.

Al- Tantawi, Muhammad Sayyid. Adab al-biwar fi Islam. Kaherah: Dar al-Nahd Misr. 1997. Ariarajah, Wesley S. Not Without My Neighbour. Tak Mungkin Tanpa Sesamaku: Isu-Isu dalam Relasi Antar-Iman. Terj. Nico A. Likumahuwa. Jakarta: BPK Gunung Mulia. 2008. As, Hornby. Oxford Advanced Learner's Dictionary. Oxford: University Printing House. 1995. Banawiratma, J.B., dkk, (ed.). Dialog Antar Umat Beragama: Gagasan dan Praktik di Indoensia. Jakarta: Mizan Publika. 2010.

Basuki, Singgit A. Sejarah, Etika, dan Teologi Agama Khongucu. Cet.1. Yogyakarta: Suka Press. 2014.

Cassanova, J. Public Religions In The Modern World. Chicago: University Press. 2008.

Casram. Membangun Sikap Toleransi Beragama dalam Masyarakat Plural. Ilmiah Agama dan Sosial Budaya. Volume 1. Nomor 2. Juli 2016.

Coward, Harold. Pluralism in the World Religions A Short Introduction. Boston: One WorldPublications. 2000.

Effendie, dan Karsan. Pendidikan Agama Buddha dan Budi Pekerti. Jakarta: Kementrian Pendidikan dan Kebudayaan. 2017.

${ }^{223}$ Raihan Ghalib Muwaffaq, 10.

74 | Imas Setiyawan, - Dialog Antar Umat Beragama Sebagai Piranti Menumbuhkan Sikap Toleransi 
Faizuddin, Ahmad dan Jaffary Awang. Dialog Antara Agama Menurut Perspektif Islam. Umran-International Journal of Islamic and Civilizational Studies. Volume 3. Nomor 2. 2016.

Fletcher, Charles D. Isma'il Al-Faruqi (1921-1986) and Interfaith Dialogue: The Man, the Cholar The Participant. Thesis Doctor of Philosophy. The Institute of Islamic Studies. Mc Gill University.

Hasani, Ismail dan Bonar Tigor Naipospos, Dari Radikalisme Menuju Terorisme, Studi Relasi dan Transfor-masi Organisasi Islam Radikal di jawa Tengah dan D.I. Yogyakarta (Jakarta: Pustaka Media, 2012), 76.

Hasyim, Umar. Toleransi dan Kemerdekaan Beragama dalam Islam Sebagai Dasar Menuju Dialog dan Kerukunan Antar Agama. Surabaya: Bina Ilmu. 1979.

IKAPI, Anggota. Alkitab Perjanjian Baru (New Testament). Jakarta: Lembaga Alkitab Indonesia. 2015.

Khamami, Rizqon A. Dialog Antar Iman dalam Perspektif Fethullah Gullen. Reigio. Volume 2, Nomor 1. 2012.

Khotimah. Dialog dan Kerukunan Antar Umat Beragama. Jurnal Ushuluddin. Volume XVII, nomor 2. 2011.

Kateregegga, Badru D, dan David W. Shenk. A Muslim and Christian Dialogue. Terj. Dialog Islam dan Kristen. Semarang: Pustaka Muria. 2007.

Kinloch, Graham C. Sociological Theory: Development and Major Paradigm. Bandung: Pustaka Setia. 2005.

Kitab Su Si (Kitab Yang Empat). Kitab Suci Agama Khongbucu. Cet X. Solo: Matakin. 2007.

Knitter, Paul F. Satu Bumi Banyak, Agama. Jakarta: BPK Gunung Mulia. 2003.

Liang, Oei King. Pelajaran Praktis Agama Khonghucu Untuk. Sekolah Lanjutan. Cet 2. Jakarta: Matakin. 1974.

Maufur. Pluralisme Agama dalam Budhisme. Universum. Volume 9. Nomor 2. Juli 2015.

Muhammad, Zainudin. Makalah: Pluralisme dan Dialog Antar Umat Beragama. Studia Philosophica et Theologica. Volume 5. Nomor 1. Maret 2005.

Mujani, Saiful. Muslim Demokrat: Islam, Budaya Demokrasi, dan Partisipasi Politik di Indonesia Pasca-Orde Baru. Jakarta: Gramedia Pustaka Utama. 2007.

Munawir, Warson Ahmad. Kamus Arab-Indonesia Al-Munawir. Yogyakarta: Balai Pustaka Progresif. 2002.

Muwaffaq, Ghalib Raihan., dkk. Makalah: Hubungan Antar Agama Dialog Antar Umat Beragama. Bandung: UIN Sunan Gunung Djati. 2018. Diakses dari bttp:// www.academia.edu/36765019/MAKALAH_HUBUNGAN_ANTAR_AGAMA_DIALOG_ANTAR_UMA T BERAGAMA (10 Desember 2018)

Muzakkir. Toleransi Beragama dan Mahabbah dalam Perspektif Sufi. Teologia. Nomor 1. Volume 23. Januari 2012.

Nawawi, Muh. Nahar. Memahami Khonghucu Sebagai Agama. Jakarta: Gramedia Pustaka Utama. 2003.

Nazmudin. Kerukunan dan Toleransi Antar Umat Beragama dalam Membangun Keutuhan Negara Kesatuan Republik Indonesia (NKRI). Journal of Government and Civil Society. Volume 1. Nomor 1. April 2017.

Palunta, Wanti Arian. Makalah: Perwujudan Hidup Beragama. Surabaya: Universitas Katolik Widya Mandala Surabaya. 2014. Diakses dari bttp:/ / www.academia.edu/8213477/ perwujudan bi-dup beragama (13 Desember 2018)

Passaddhi, Ariya Febrian. Sila dan Kebaikan. Diakses dari bttp:// www.academia.edu/6539607/PELA- 
KSANAAN SILA DALAM AGAMA BUDDHA MENIMBULKAN KEBAI KAN BAGI DIRI SENDIRI DAN ORANG LAIN (04 Desember 2018)

Penyusun, Tim. Kamus Bahasa Indonesia. Jakarta: Pusat Bahasa Departemen Pendidikan Nasional. 2008.

Qadir, Zuly. Gerakan Sosial Islam: Manifesto Kaum Beriman. Yogyakarta: Pustaka Pelajar. 2009.

RI, Agama Departemen. Bingkai Kerukunan Umat Beragama di Indonesia. Jakarta: Balitbang Agama Proyek Peningkatan Kerukunan Hidup Umat Beragama di Indonesia. 1997.

Rifa'i, Afif. Dialektika Pemikiran dalam Dialog Antar Umat Beragama: Studi Kasus Forum Persaudaraan Umat Beriman (FPUB) DI.Yogyajarta. Jurnal Pemberdayaan Masyarakat. Volume 1. Nomor 1. 2017.

Riyanto, Armada E. Dialog Interreligius: Historis, Tesis, Pergumulan, Wajah. Yoyakarta: Kanisius. 2010.

Ruslan, Idrus. Etika Islam dan Semangat Pluralisme Agama di Era Global. Al-AdYaN. Volume V. Nomor I. Januari-Juni 2010.

Scumman, Olaf. "Some Reflection on the Meaning and Aims of Interfaith Dialogue", in Dialogue and Beyond: Christians and Muslims, Together on the Way. Switzerland: The Lutheran World Moderation. 2003.

Sena, Widya Made Gusti I. Konsep Kosmologi Dalam Perspektif Agama Buddha. Vidya Sambita Jurnal Penelitian. Diakses dari http://sim.ibdn.ac.id/app-assets/repo/repo-dosen10170112-3816-58.pdf (9 Desember 2018)

Setio, Ongky. Pandangan Agama Khonghucu Mengenai Dialog Menuju Perdamaian Dunia. June 2012. Diakses dari http:// wmw.spocjournal.com/religi/81-pandangan-agama-khongbu-cumengenai-dialog-menuju-perd-amaian-dunia.btml (12 Desember 2018)

Shadra, Mula. Al-Hikmah al-Muta Aliyah di Asfar al-Arba'ah al- Aqliyyah. Volume 3. Beirut: Dar Ihya' al-Turath al-'Arabi. 1981.

Shihab, Alwi. Islam Inklusif; Menuju Sikap Terbuka dalam Beragama. Bandung: Mizan. 1997.

Sintiyani, Ayu Ani dan Siti Maftuhah. Harapan dan Tantangan Dialog Antar Umat Beragama. Jurusan Perbandingan Agama. Fakultas Ushuluddin dan Filsafat. Bandung: Universitas Islam Gunung Djati. 2013. Diakses dari http://wmw.academia.edu/5367600/Dialog Antar U-mat Ber-agama (10 Desember 2018)

Smith, Huston. Agama-Agama Manusia. Jakarta: Yayasan Obor Indonesia. 1991.

Siradj, Aqil Said. Islam Kebanggan; Fiqib Demokratik Kaum Santri. Jakarta: Pustaka Ciganjur. 1999.

Sudjiangi. Pembinaan Kerukunan Hidup Umat Beragama: 50 Tabun Kemerdekaan Republik Indonesia. Jakarta: Departemen Agama RI. 1995/1996.

\section{Sumber Internet}

Aslati. Toleransi Antar Umat Beragama Dalam Perspektif Islam (Suatu Tinjauan Historis). Diakses dari https://media.neliti.com/media/publications/40259-ID-toleransi-antar-umat-beragamadalam-perspekt-if-islam-suatu-tinjauan-bistoris.pdf (04 Desember 2018)

Daruma. 4 Nostra Aetate Art 1 Gereja Katolik Memandang. Diakses dari https: / / www.coursehero.co-m/file/p1 qo5mp/4-Nostra-Aetate-Art-1-Gereja-Katolikmemandang-pentingnya-agama-dalam-kebidu-pan/ (pada 8 Desember 2018)

Mcdowell, Crystal. What Does the Bible Say About Tolerance? A Christian Study. Diakses dari bttp:-// www.whatchristianswanttoknow.com/what-does-the-bible-say-about-tolerance-a-christianstydy/(10 D-esember 2018) 
Melati, Cik. Toleransi dalam Perspektif Agama Hindu. Diakes dari bttps:// www.scribd.com/doc/136-750359/Toleransi-Dalam-Perspektif-Agama-Hindu Desember 2018)

Pos Bali Online, diakses dari https:// wmw.posbali.id/dalam-bindu-toleransi-adalab-keyakinan/ (11 Desem-ber 2018)

Remetwa, Dion. Dialog Antar Agama. Diakses dari http://dimasche.wordpress.com/2012/05/21/dialog (12 Desember 2018)

Saksi-saksi Yehuwa, diakses dari https://www.jw.org/id/publikasi/majalab/g201508/kataalkitab-tentang-toleransil (8 Desember 2018)

Yayasan Lembaga Sabda. Dialog Kebenaran Agaphe. Diakes dari https: / alkitab.sabda.org/ resource.p-hp?topic=1011 \&res=jpz (10 Desember 2018)

http:// digilib.uin-suka.ac.id/2547/1/BAB\%20I\%2CV\%2C\%20DAFTAR\%20PUSTAKA.pdf, (12 De-sember 2018)

http:/ / eprints.walisongo.ac.id/3915/3/104311013 Bab2.pdf (13 Desember 2018)

\section{Informan}

Suwignjo, Ketua sekaligus Pendeta di Gereja Kristen Jawi Wetan Surabaya.

Ilidius Yosef Sumarno, Romo dari agama Katolik. 